\title{
Quantitative determination of cyanoacetic acid content in teriflunomide drug substance by ion chromatography using conductivity detector
}

\author{
Kishore V. Merusomayajula ${ }^{1,2^{*}}$ (D), T. Siva Rao ${ }^{2^{*}}$, K. Rama Srinivas $^{1}$ and Ch. V. Sathyendranath ${ }^{1}$
}

\begin{abstract}
Background: The current study focuses on the development and validation of an analytical method for quantifying cyanoacetic acid (CAA) in teriflunomide drug substance using a high-performance ion chromatography (IC) with cation suppressed conductivity detection (TFM). Water was used as the diluent for preparing the sample solution, which was injected into a standard chromatographic device with $250 \mathrm{~mm}, 4.0 \mathrm{~mm} \mathrm{ID}$, and $5.0 \mu \mathrm{m}$ particle size Metrosep A Supp 5 Ion exchange column and a suppressed conductivity detector. At a flow rate of $0.6 \mathrm{~mL} \mathrm{~min}^{-1}$ and a temperature of $40^{\circ} \mathrm{C}$, the mobile phase was delivered in an isocratic mode.

Results: CAA and TFM had retention times of 12.78 and $15.82 \mathrm{~min}$, respectively. CAA has a limit of detection (LOD) of $33 \mu \mathrm{g} / \mathrm{g}$ and a limit of quantification (LOQ) of $101 \mu \mathrm{g} / \mathrm{g}$, respectively. For LOD and LOQ accuracy, the percentage RSD of CAA is 1.7 and 1.2, respectively. The average CAA recovery percentage was found to be between 98.6 and $100.1 \%$. With a value of 0.9998 , the calibration curve yielded an excellent linear correlation coefficient for CAA. According to the $\mathrm{ICH}$ guidelines, all verification parameters are within the range, indicating that the system is stable.

Conclusion: The elution time and run time in the currently developed ion chromatography analytical method have been reduced, demonstrating that the method is cost-effective and generally accepted, as well as simple and functional, and can be used in routine quality control tests in the industry.
\end{abstract}

Keywords: Cyanoacetic acid, Teriflunomide, Ion chromatography, Validation, Conductivity detector

\section{Background}

Chemically, teriflunomide (TFM) (Fig. 1) is known as (2Z)-2-cyano-3-Hydroxy-N-[4-(terifluoromethyl)

phenyl]. Butenamide-2-Butenamide-2-Butenamide-2Butenamide-2-But $\mathrm{C} 12 \mathrm{H} 9$ F3N2O2 is its molecular formula, with a molecular weight of $270.21 \mathrm{~g} / \mathrm{mol}$ [1]. It is the active metabolite of leflunomide [2], and it

\footnotetext{
* Correspondence: kishorechem6327@gmail.com;

sivaraotvalluri.16@gmail.com

'Aurobindo Pharma Limited, Survey No. 71\&72, Indrakaran Village, KandiMandal, Sangareddy District-502329, Telangana, India

2Department of Inorganic and Analytical Chemistry, AU College of Science and Technology, Andhra University, -530003, Visakhapatnam, Andhra Pradesh, India
}

inhibits pyrimidine synthesis, acting as an immunoteflunomide's in vivo activity [3-6]. It has been studied as a potential treatment for multiple sclerosis (MS). The disease process in MS is stopped swiftly by dividing cells like activated $\mathrm{T}$ cells. It can minimize the risk of infection in comparison with medications similar to chemotherapy [7] because of its modest impact on the immune system. The first Sanofi to marwas under the Aubagio brand name. Aubagio shall be taken orally at a dose of $14 \mathrm{mg}$ once a day. The adverse effects of TFM include liver disorders, 


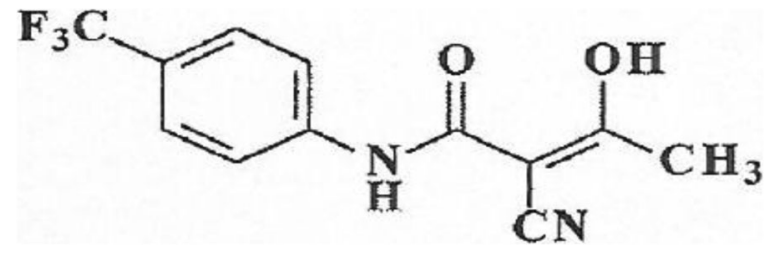

Fig. 1 Chemical structure of teriflunomide

influenza, hair loss or thinning hair, nausea, diarrhea, burning or prickly skin, and numbness or tingling in your hands or feet that is not related to your MS symptoms. The US Food and Drug Administration approved the treatment in 2012 [8] and the European Union in 2013 [9], respectively.

Cyanoacetic acid (CAA) (Fig. 2) is used as a precursor in the production of TFM. CAA is coupled with another beginning material, aniline 4-(tripfluoromethyl) to make intermediate (i.e., 2-cyano-N-(4trifluoromethyl) phenylacetamide). This intermediate combines with acetyl chloride to produce TFM in the presence of sodium hydroxide and acetone. The synthesis pathway of TFM is shown in Fig. 3. During the entire procedure, CAA traces may be present in TFM. In terms of safety levels, therefore, the CAA control is needed in TFM. CAA is measured by a limit of $500 \mu \mathrm{g} / \mathrm{g}$ much below the respective threshold criterion. Various approaches have been found in the literature review to estimate TFM in API, commercial formulations, and biological fluids. Comprehensive information on the many methods accessible can be obtained by chromatographic methods such as HPLC [10], HPLC [11-14], LC MS [15-19], and CAA material [20-23] by various methods. Ion chromatography (IC) [24-29] has recently emerged as a popular analytical tool for determining inorganic cations and organic acids in a variety of matrices. As

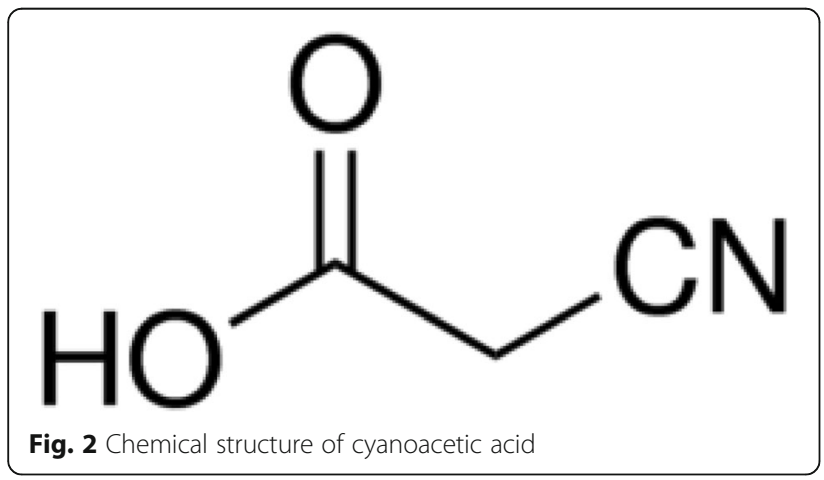

far as we are aware, no IC experiments have been made to date in order to identify CAA content in TFM. In this context, we have developed a Green Ion Chromatography technique for the determination and validation of CAA in TFM in compliance with $\mathrm{ICH}$ and the FDA guidelines [30-32] with a reduced run time. CAA content detection process is relatively sensitive to ion-exchange chromatography together with the analytical conductometric detector approach developed and validated that may simply be deployed in routine testing and reporting quality control laboratories.

\section{Methods}

Chemicals, reagents, and standards

Teriflunomide and its impurities, which include the 2-Isomer of teriflunomide, the 3-Isomer of teriflunomide, and N-[4-(Trifluoromethyl)phenyl] 2-Cyano-N[4-(Trifluomethyl)phenyl]-acetamide, 4-(Trifluomethy1)aniline, 2-Cyano-N-[4-(Trifluomethyl)phenyl]-acetamide and ethyl teriflunomide were gifted by Aurobindo Pharma Limited. From Sigma-Aldrich procured acetic and cyanoacetic acids. Analytical reagent grade sodium carbonate, sodium bicarbonate, and sulfuric acid were purchased from Merck India, and HPLC grade water was prepared using Milli Q-Water system.

\section{Chromatographic conditions}

An ion chromatograph (Metrohm 930 compact IC Flex) with conductometric detector and Metrohm 863 Compact Auto sampler or equivalent with Magic IC Net 3.0 is used. And a Chromeleon 6.8version Ion Chromatograph (Dionex ICS5000) with conductivity detector and AS-AP Auto Sampler or equivalent (for Ruggedness). Metrosep A Supp 5, 6.1006.530, (250 $\mathrm{mm} \times 4.0 \mathrm{~mm}) 5 \mu \mathrm{m}$ polyvinyl alcohol particles with quaternary ammonium groups were used in the panel. The mobile phase contains 504 mg sodium bicarbonate and $53 \mathrm{mg}$ sodium carbonate in $1000 \mathrm{~mL}$ of water that has been filtered through a 0.45 -micron porosity membrane. For the Metrohm system, the suppressor regeneration solution is $2.8 \mathrm{~mL}$ of sulfuric acid in $1000 \mathrm{~mL}$ of water and for the Dionexsystem and 2.0 $\mathrm{mL}$ of sulfuric acid in $4000 \mathrm{~mL}$ of water. Mill QWater used as diluent. The chromatographic conditions are shown in Table 1.

\section{Analysis performed by using suppressor Preparation of standard solution}

A stock solution $(0.0005 \mathrm{mg} / \mathrm{mL})$ was prepared by accurately weighing and transferring about $50 \mathrm{mg}$ of CAA reference standard into a $100 \mathrm{~mL}$ clean dry volumetric flask added with $70 \mathrm{~mL}$ of diluents and 

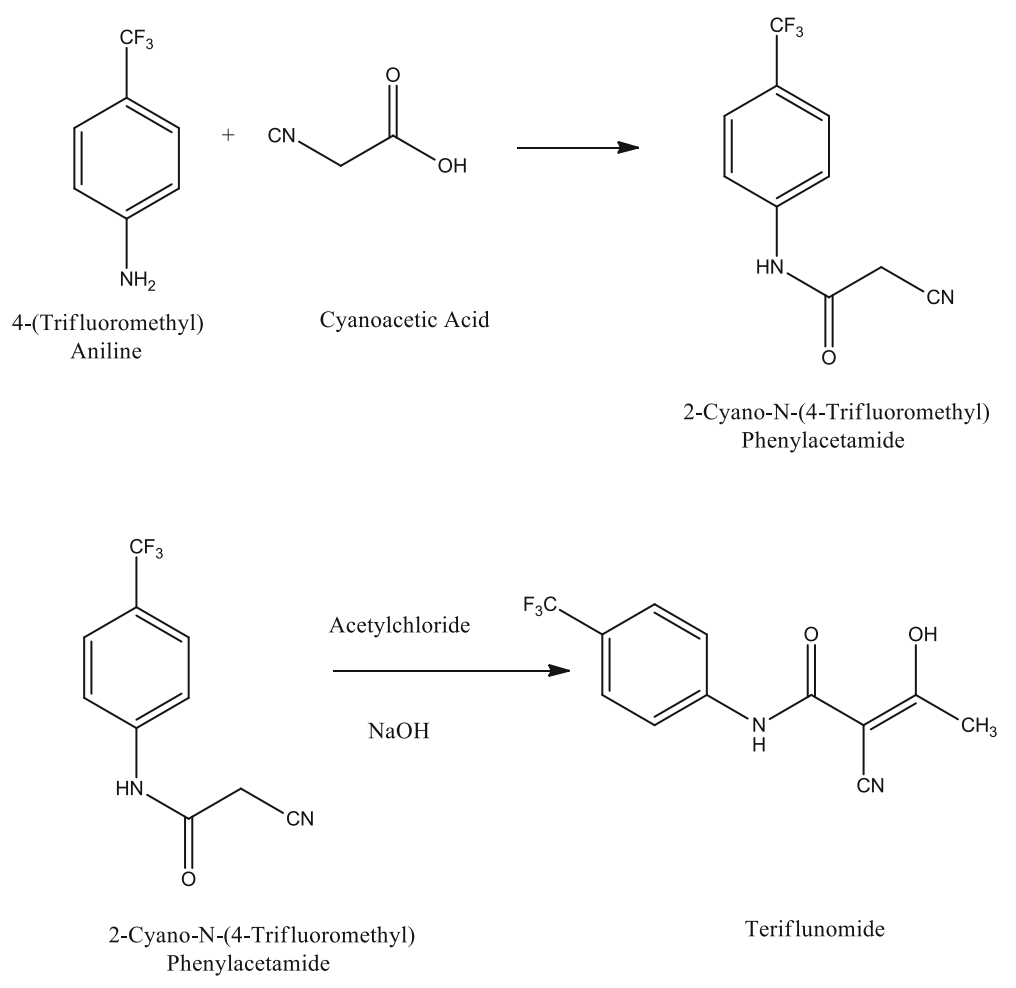

Fig. 3 Typical synthesis scheme of TFM

sonicate to dissolved make up to volume with diluent. Diluted $5 \mathrm{~mL}$ of this solution to $100 \mathrm{~mL}$ with diluents. Further diluted $2 \mathrm{~mL}$ of this solution to $100 \mathrm{~mL}$ with diluent.

\section{Preparation of sample solution}

Accurately weighed and transferred about $50 \mathrm{mg}$ of sample in $50 \mathrm{~mL}$ clean dry volumetric flask added with 30 $\mathrm{mL}$ of diluent and sonicated for $3 \mathrm{~min}$ make up to volume with diluents. Filtered through $0.45 \mu \mathrm{m}$ porosity membrane filter.

\section{Method development and optimization}

CAA is a precursor in the synthesis of TFM. Method development for quantification of CAA content in TFM started with a solubility of CAA and drug substance, based on the solubility study water, is selected as diluent. Preliminary tryouts were carried out based on the retention of CAA and peak shape with different columns using like Metrosep Super-Sep, Metrosep A Supp 3, Metrosep Anion Dual 2, and Metrosep A Supp 5 column, and different mobile phase combinations were used to investigate the evaluation of the analyte with sodium carbonate, sodium bicarbonate, formic acid, potassium phthalate, and octane-1-sulfonic acid sodium salt. A better chromatographic separation occurred at $504 \mathrm{mg}$ of sodium bicarbonate and $53 \mathrm{mg}$ of sodium carbonate in 1000 $\mathrm{ml}$ of water buffer, at a flow rate of $0.6 \mathrm{~mL} \mathrm{~min}^{-1}$ with Metrosep A Supp 5, 6.1006.530, $(250 \mathrm{~mm} \times 4.0$ $\mathrm{mm}) 5 \mu \mathrm{m}$ at $40{ }^{\circ} \mathrm{C}$ temperature.

Table 1 Chromatographic conditions

\begin{tabular}{ll}
\hline Column & Metrosep A Supp 5, 6.1006.530,(250 $\mathbf{m m ~} \times \mathbf{4 . 0} \mathbf{~ m m}) \mathbf{5} \boldsymbol{\mu m}$ \\
\hline Flow & $0.6 \mathrm{~mL} / \mathrm{min}$ \\
Column oven temp & $40^{\circ} \mathrm{C}$ \\
Injection Volume & $100 \mu \mathrm{l}$ \\
Data acquisition time & $30 \mathrm{~min}$ \\
\hline
\end{tabular}




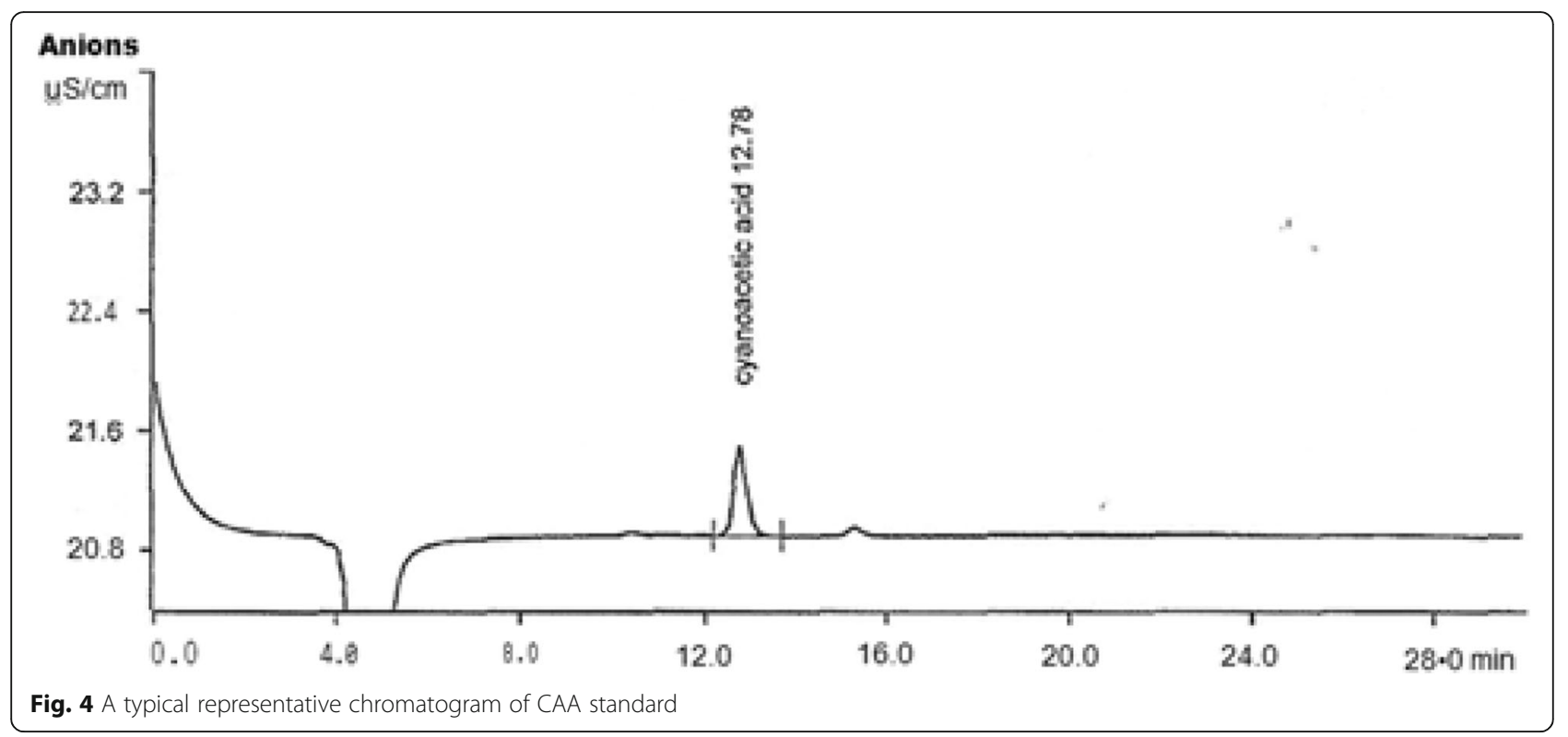

\section{Results}

\section{Method validation}

The objective of this research work was to quantitatively determine CAA in TFM. According to ICH [31] and FDA [32, 33], the key analytical parameters that require for validation were Accuracy, Precision, Linearity, Recovery, Limit of Detection, Limit of Quantification, and Ruggedness.

\section{Specificity}

Specificity's special feature is the method's capacity to quantify analyte in the presence of all possible contaminants. The retention time (RT) of the standard analytical solution and the sample solution (CAAspiked solution) was identified according to the test technique and injecting into IC according to the methodology. Standard retention time of $12.78 \mathrm{~min}$

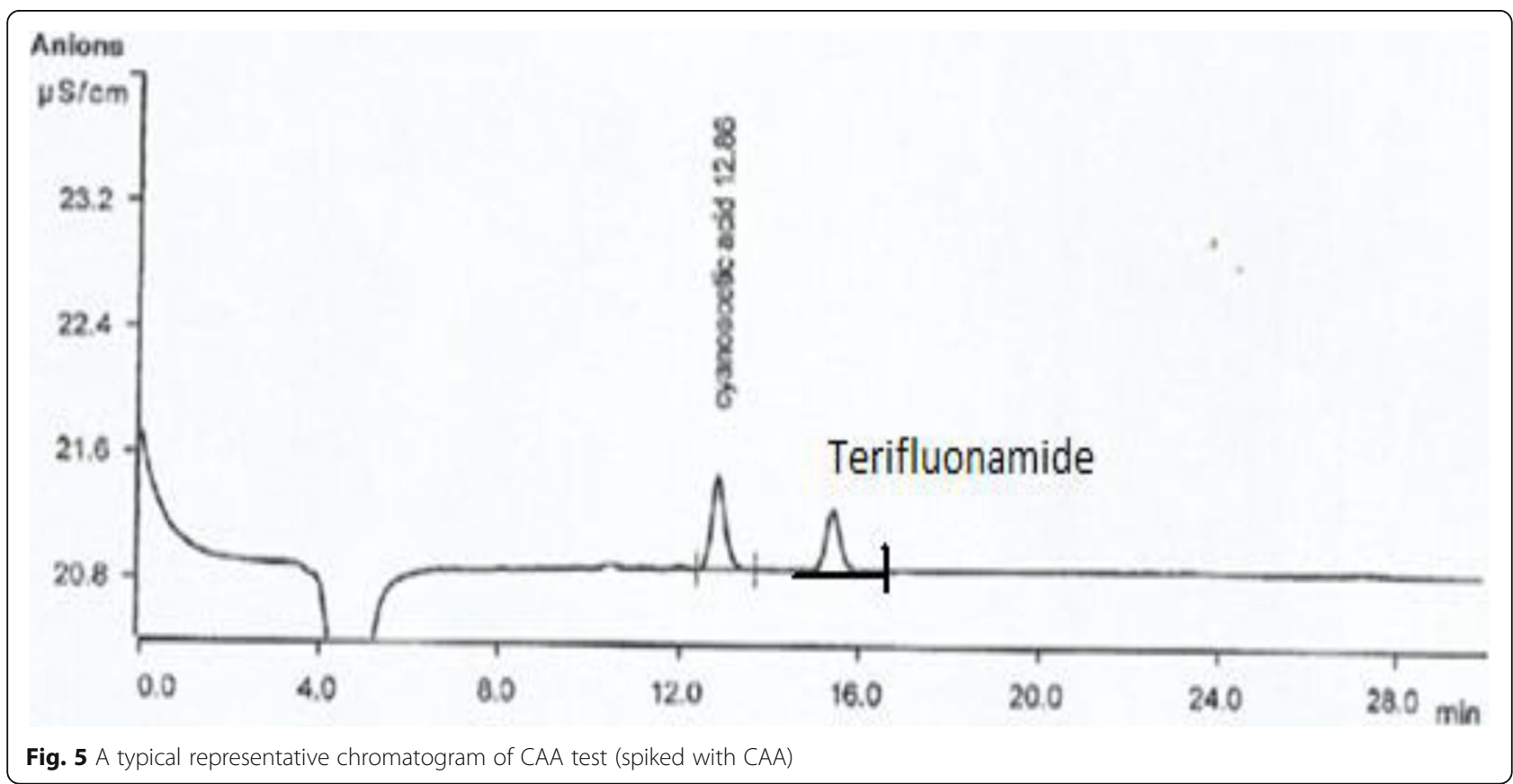




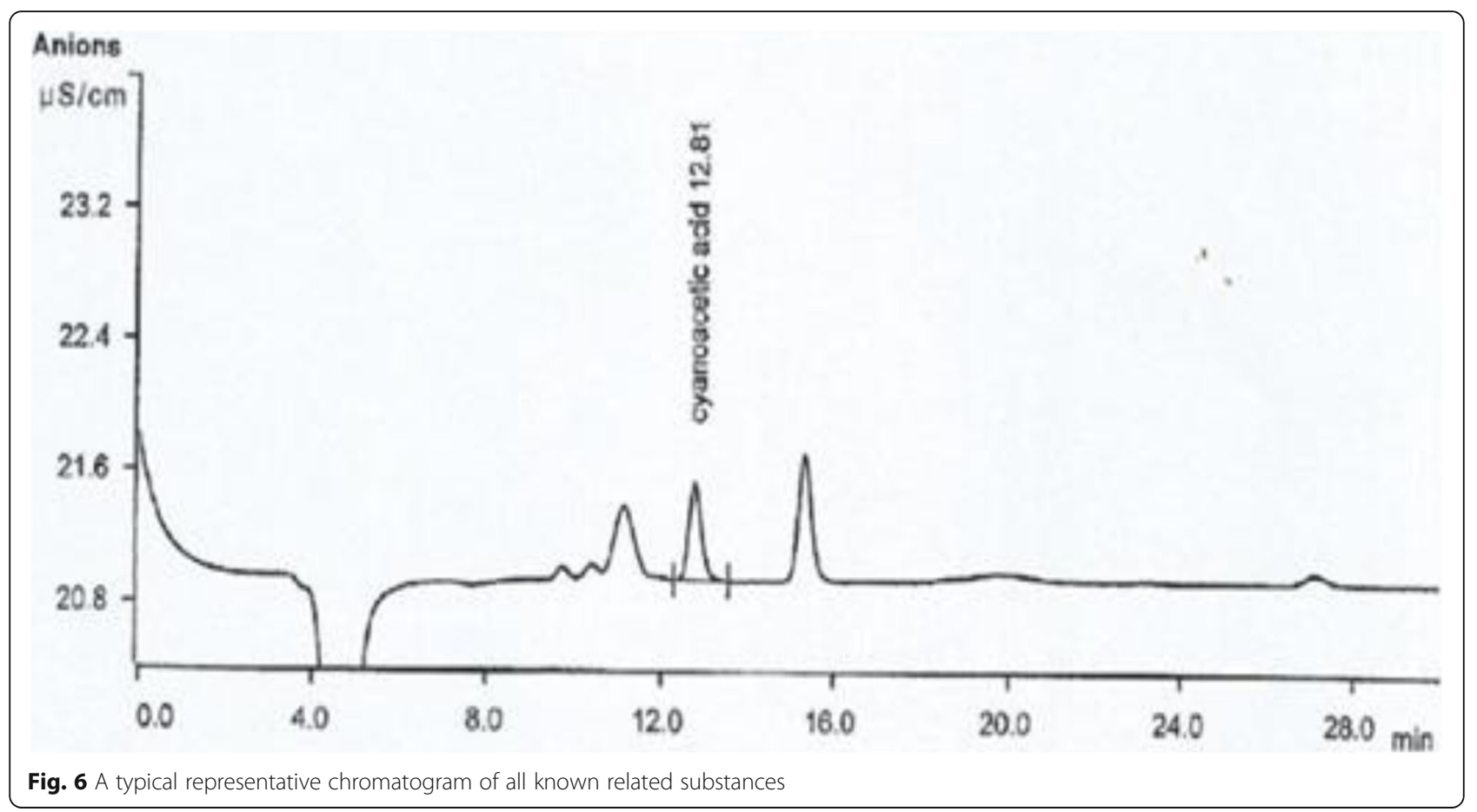

and sample solution of $12.86 \mathrm{~min}$ were recorded. For specificity determination, the interference of diluents peaks and determination of CAA were studied. TFM spiked with all known related substances 2-Isomer of teriflunomide $(0.15 \mathrm{mg})$, 3-Isomer of teriflunomide (0.15 mg), N-[4-(Trifluoro-methy1)phenyl]-acetamide (0.15 mg),4-(Trifluoromethyl)aniline $\quad(0.10 \mathrm{mg}), 2-\mathrm{Cy}-$ ano-N-(4-(Trif1uoro-methyl)phenyl]-acetamide $\quad(0.10$ $\mathrm{mg})$, and Ethylteriflunomide $(0.10 \mathrm{mg})$ and residual impurities which may interfere with cyatioacetic acid [Aceticacid (0.05\%)] including CAA at about specification level are prepared in triplicate and injected into IC as per methodology. CAA peak only integrated in chromatograms. Specificity chromatograms have been shown in Figs. 4, 5, and 6 correspondingly. From the above data, there is an absence of interference in the presence of all known related substances and residual impurities with CAA. Hence, it was concluded that the method is specific for the determination of the content of CAA in TFM.

\section{Linearity}

Linearity is a requirement in correlation and linear regression analysis. To prove this, the CAA reference standard was used to develop a series of solutions at the concentration levels ranging from 10 to $150 \%$ of the specification level injected into IC as per methodology. The linearity was determined from this data

Table 2 Statistical data of linearity

\begin{tabular}{llll}
\hline Sample ID (\%Level) & Concentration $(\boldsymbol{\mu g} / \mathbf{m L})$ & Area $[(\mu \mathbf{S} / \mathbf{c m} \times \mathbf{m i n}]$ & Statistical analysis \\
\hline LOQ level & 0.101 & 0.0373 & Slope \\
$25 \%$ level & 0.126 & 0.0506 & Intercept \\
$50 \%$ level & 0.252 & 0.1004 & \\
$75 \%$ level & 0.377 & 0.1483 & STEYX \\
$100 \%$ level & 0.503 & 0.197 & \\
$125 \%$ level & 0.629 & 0.2478 & Correlation coefficient \\
$150 \%$ level & 0.755 & 0.3000 & 0.002 \\
\hline
\end{tabular}




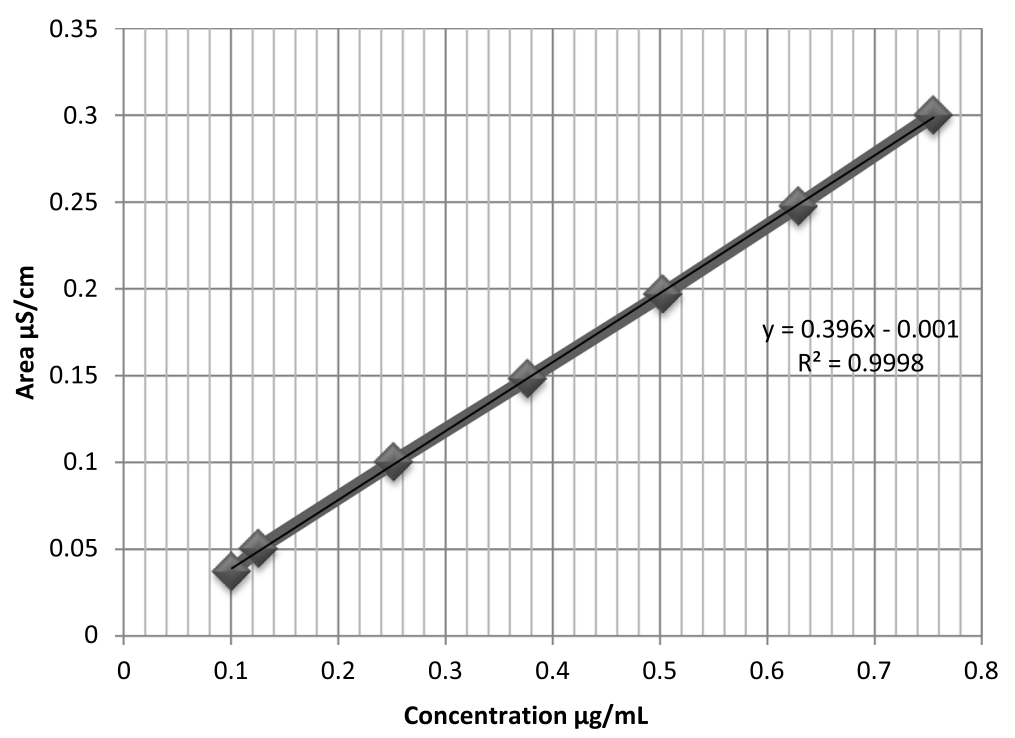

Fig. 7 A typical representative linearity plot (concentration vs area)

following the establishment of the LOQ level from LOQ to $150 \%$ of the level and shown below. The correlation coefficient of acceptance criteria must be more than 0.990 and the value achieved was 0.9998 . Table 2 represents the linearity data and Fig. 7 shows the linearity graph.

\section{$\angle O D$ and $\angle O Q$}

LOD and LOQ are terms used to describe the smallest analysis concentration, which can be detected consistently by an analytical procedure. Linearity data were forecasted to predict the detection limit (LOD)

Table 3 Representation of LOD and LOQ results

\begin{tabular}{lll}
\hline Injection ID & \multicolumn{2}{l}{ Area $\{(\mu \mathrm{S} / \mathrm{cm}) \times \mathrm{min}\}$} \\
\cline { 2 - 3 } & LOD & LOQ \\
\hline 1 & 0.0113 & 0.0372 \\
2 & 0.0118 & 0.0374 \\
3 & 0.0111 & 0.0372 \\
4 & 0.0116 & 0.0371 \\
5 & 0.0115 & 0.0382 \\
6 & 0.015 & 0.0369 \\
Mean & 0.0115 & 0.0373 \\
SD & 0.0002 & 0.0005 \\
\%RSD & 1.7 & 1.3 \\
Conc. $(\mu \mathrm{g} / \mathrm{ml})$ & 0.033 & 0.101 \\
Conc. $(\mu \mathrm{g} / \mathrm{g})$ w.r.t sample & 33 & 101 \\
\hline
\end{tabular}

and the quantification limit (LOQ) values for the CAA. By developing solutions for these projected concentrations, each predicted concentration has been precisely validated and each solution has been injected six times into IC, depending on the procedure. The approval requirement for RSD is not more than $10.0 \%$ for LOQ and $33.0 \%$ for LOD. The LOQ and LODs for CAA listed below are not more than $0.05 \%$ below the specified threshold. Therefore, the testing procedure is accurate for measuring CAA at the LOQ and LOD TFM values indicated. LOD and LOQ precision data are made known in Table 3.

\section{Accuracy (recovery)}

A test method is said to be accurate when it measures what it is supposed to measure. That means it is able to measure the true amount or concentration of a substance in a sample. To demonstrate accuracy, sample solutions were prepared in triplicate using TFM as such and spiked with a known amount of CAA at about LOQ level $50 \%, 100 \%$, and $150 \%$ of specification level as per the test method and injected each solution into IC as per methodology. The acceptance criterion is that recovery should be between 80 and $120 \%$. The data concluded that the average recovery of CAA is $99.3 \%$ and in the well in the acceptance limit. Data are shown in Table 4.

\section{Precision}

The equipment and the technique were tested for their precision. Precision examination of the system 
Table 4 Representation of accuracy results LOQ, 50\% to 150\% level

\begin{tabular}{|c|c|c|c|c|c|}
\hline \% level/sample ID & $\begin{array}{l}\text { Amount added } \\
(\mu \mathrm{g} / \mathrm{g})\end{array}$ & $\begin{array}{l}\text { Amount found } \\
(\mu \mathrm{g} / \mathrm{g})\end{array}$ & $\%$ recovery (between 80 and $120 \%$ ) & Average recovery & \%RSD \\
\hline \multirow[t]{3}{*}{ LOQ } & 99 & 97 & 98 & 98.7 & 0.6 \\
\hline & 100 & 99 & 99 & & \\
\hline & 98 & 97 & 99 & & \\
\hline \multirow[t]{3}{*}{$50 \%$} & 247 & 246 & 99.6 & 100.1 & 0.6 \\
\hline & 245 & 245 & 100 & & \\
\hline & 248 & 250 & 100.8 & & \\
\hline \multirow[t]{3}{*}{$100 \%$} & 497 & 496 & 99.8 & 98.6 & 1.7 \\
\hline & 490 & 474 & 96.7 & & \\
\hline & 490 & 486 & 99.2 & & \\
\hline \multirow[t]{3}{*}{$150 \%$} & 747 & 742 & 99.5 & 99.6 & 0.4 \\
\hline & 740 & 734 & 99.2 & & \\
\hline & 741 & 741 & 100 & & \\
\hline
\end{tabular}

with repeatability and reproducibility (ruggedness). The efficiency of the procedure was tested with replicate injections of normal and sample solutions. The efficiency of the ion chromatography system was evaluated six times throughout the day in chromatographic settings with a standard solution (system precision). The relative standard deviation of CAA is $0.5 \%$. The intraday (method accuracy) variance was the repeatability and the relative standard variance for CAA content was $0.8 \%$. The interday variance (roughness) gave intermediate precision and was $1.7 \%$ relative standard deviation for CAA content. By assessing six sample solutions independently and adding CAA at a predetermined amount, the reproducibility and the reproduction of the procedure in various settings,

Table 5 Statistical data of precision for CAA

\begin{tabular}{|c|c|c|c|}
\hline \multicolumn{2}{|c|}{ System precision } & \multirow{2}{*}{$\begin{array}{l}\text { Method precision } \\
\text { CAA }(\mu \mathrm{g} / \mathrm{g})\end{array}$} & \multirow{2}{*}{$\begin{array}{l}\text { Intermediate precision } \\
\text { CAA }(\mu \mathrm{g} / \mathrm{g})\end{array}$} \\
\hline Injection No & $\overline{\text { CAA area }}$ & & \\
\hline 1 & 0.1993 & 502 & 484 \\
\hline 2 & 0.1999 & 497 & 488 \\
\hline 3 & 0.1977 & 504 & 478 \\
\hline 4 & 0.1986 & 502 & 494 \\
\hline 5 & 0.1985 & 502 & 485 \\
\hline 6 & 0.1983 & 509 & 501 \\
\hline Mean & 0.1987 & 503 & 488 \\
\hline SD & 0.001 & 3.88 & 8.12 \\
\hline$\%$ RSD & 0.5 & 0.8 & 1.7 \\
\hline
\end{tabular}

the degree of reproductivity gained through the analysis of the same sample (used under the method precise) utilizing separate column series, with a different analyst preparing fresh standards and new mobile phases on different days, has been identified as a robust procedure. Table 5 show the precision (system precision, method precision, and ruggedness) experiment performance.

\section{Robustness and system suitability}

To demonstrate robustness, a standard solution (for evaluating system suitability) and a sample solution spiked with CAA at specification level were prepared according to the test method and injected into the IC under various intentionally varied conditions to assess system suitability and the method's ability to remain unaffected. The altered conditions include a $10 \%$ change in flow rate, a $5{ }^{\circ} \mathrm{C}$ increase in column oven temperature, and column variance. The column quality, as calculated by the CAA peak, must be no less than 4000 theoretical plates and the asymmetry must be not more than 2.0. Furthermore, the RSD for six injections of the regular solution in peak areas is less than 5.0\%. The outcomes of these experiments are summarized in Tables 6 and 7 below.

The outcomes of the device suitability tests at each of the different conditions met the test procedure's specifications. Also, the chromatograms of TFM spiked with CAA at specification level obtained from the various robustness conditions outlined above show that the RT of CAA obtained 
Table 6 Representation of overall statistical data of ruggedness

\begin{tabular}{|c|c|c|c|c|}
\hline \multirow[t]{2}{*}{ Parameter } & \multirow[t]{2}{*}{ Variation } & \multicolumn{3}{|l|}{ System suitability } \\
\hline & & Theoretical plates & Asymmetry & \%RSD \\
\hline STP* & - & 6371 & 1.6 & 1.0 \\
\hline \multirow[t]{2}{*}{ Flow rate* } & $-10 \%$ & 6696 & 1.5 & 0.1 \\
\hline & $+10 \%$ & 5778 & 1.6 & 0.9 \\
\hline \multirow[t]{2}{*}{ Temperature* } & $-5^{\circ} \mathrm{C}$ & 6430 & 1.5 & 0.2 \\
\hline & $+5^{\circ} \mathrm{C}$ & 6337 & 1.5 & 0.2 \\
\hline Column lot variation** & Batch/lot variation & 7411 & 1.3 & 0.6 \\
\hline
\end{tabular}

${ }^{*} 1$ st column, ${ }^{* *} 2$ nd column

at each of the varied conditions is not significantly different from that of the STP condition. As a result, the test method is found to be reliable for determining CAA content in TFM across the range of changes investigated for each of the above parameters.

\section{Discussion}

Ion chromatography, a form of liquid chromatography, determines ionic group concentrations on the basis of their interplay with a resin. Column components absorb the ions while the solution of the sample passes through a pressured column. When the eluent or ion extraction liquid flows through the column, the separation starts from the column. Different retention durations show various compounds in the sample and simultaneously measure ion concentrations in the sample. A detector result record called a chromatogram comprises of electrical conductance vs. time when the analyte passes through the chromatography apparatus. Suitable and stability signifying Ion chromatography method was developed with Metrosep A Supp 5, 6.1006.530, $(250 \mathrm{~mm} \times$ $4.0 \mathrm{~mm}) 5 \mu \mathrm{m}$ polyvinyl alcohol particles with quaternary ammonium groups and with carbonate buffer containing a mixture of sodium carbonate $(\mathrm{Na} 2 \mathrm{CO} 3)$ and sodium bicarbonate (NaHCO3) dissolved in water to quantitatively determine CAA in TFM. Isocratic elution mode selected at $40{ }^{\circ} \mathrm{C}$ temperature with $0.6 \mathrm{~mL}$ flow rate.
CAA was determined using several analytical methods in diverse matrices. On the other hand, there is no IC method reported for the determination of CAA in any matrix according to the literature. Since no solvent was needed in this IC approach for estimating CAA material, it was an ecologically benign IC procedure with a quick 30 -min running time. This IC technique is suitable for daily analysis. Recorded RT was $12.8 \mathrm{~min}$ for CAA and $15.8 \mathrm{~min}$ for TFM, which indicated that the retention period was robust and successful. As a result, it is possible to analyze a large number of samples is possible. The approach is linear with a coefficient of correlation $\left(r^{2}\right)$ of 0.9998 (Fig. 7 and Table 2). The intraday and interday relative standard deviations were both less than $1.7 \%$ (Table 5). LOD as low as $33 \mu \mathrm{g} / \mathrm{g}$ and LOQ as $101 \mu \mathrm{g} / \mathrm{g}$ were estimated to identify and quantify markers in a resolution sample (Table 3). Excellent recovery was also achieved in acceptable limits for the presented approach (Table 4). The observed validation parameters and statistical data were within the limits of acceptance for ICH and USP [31, 32, and 33]. Table 8 highlights the experimental results compared to other approaches provided in the literature.

\section{Conclusions}

A simple and sensitive ion chromatography method was developed and validated for the concurrent

Table 7 Representation of overall statistical data \%RSD for ruggedness

\begin{tabular}{|c|c|c|c|c|c|c|c|c|c|c|}
\hline \multirow[t]{2}{*}{ Variation } & & \multicolumn{9}{|c|}{ Standard area } \\
\hline & & 1 & 2 & 3 & 4 & 5 & 6 & Mean & SD & \%RSD \\
\hline Standard conditions & & 0.1593 & 0.1629 & 0.1629 & 0.1628 & 0.1631 & 0.1637 & 0.1625 & 0.0016 & 1.0 \\
\hline \multirow[t]{2}{*}{ Flow rate $(0.6 \mathrm{~mL} / \mathrm{min})$} & $-10 \%$ & 0.1844 & 0.1846 & 0.1843 & 0.1843 & 0.1846 & 0.1849 & 0.1845 & 0.0002 & 0.1 \\
\hline & $10 \%$ & 0.1502 & 0.1488 & 0.151 & 0.1501 & 0.1515 & 0.1524 & 0.1507 & 0.0013 & 0.8 \\
\hline \multirow[t]{2}{*}{ Column oven temp $\left(40^{\circ} \mathrm{C}\right)$} & -5 & 0.1661 & 0.1667 & 0.1664 & 0.1665 & 0.1671 & 0.1667 & 0.1666 & 0.0003 & 0.2 \\
\hline & 5 & 0.1661 & 0.1657 & 0.1653 & 0.1657 & 0.1653 & 0.1652 & 0.1656 & 0.0003 & 0.2 \\
\hline
\end{tabular}


Table 8 Comparison of various methods for determination of CAA with published results in the literature

\begin{tabular}{|c|c|c|c|}
\hline Method & Conditions & Result & Reference \\
\hline $\begin{array}{l}\text { UV- } \\
\text { spectrophotometer }\end{array}$ & Diazosulfanic acid + sodium hydroxide solution, read at $490 \mathrm{~nm}$ & Read against reagent blank and test solution & {$[20]$} \\
\hline $\begin{array}{l}\text { Calorimetric } \\
\text { method }\end{array}$ & Diazosulfanic acid + sodium carbonate solution & Read against reagent blank and test solution & [22] \\
\hline $\begin{array}{l}\text { Gas } \\
\text { chromatography } \\
\text { method }\end{array}$ & $\begin{array}{l}\text { Column, } 1 \mathrm{~m}(3-4) \mathrm{mm} \text {; sorbent, } 10 \% \text { poly(ethylene glycol) } \\
\text { sebacate on Polysorb I; temperature regime: column } \\
\text { thermostat, } 100^{\circ} \mathrm{C} \text {; DTP detector, } 150^{\circ} \mathrm{C} \text {; evaporator, } 300^{\circ} \mathrm{C} \text {; } \\
\text { detector current, } 190 \mathrm{~mA} \text {; carrier gas (helium) flow rate, } 30 \mathrm{ml} / \\
\text { min; sample volume } 0.4 \mu \mathrm{l}\end{array}$ & Recovery ranges from 97.95 to $101.1 \%$ & [21] \\
\hline $\begin{array}{l}\text { High-performance } \\
\text { liquid } \\
\text { chromatography }\end{array}$ & $\begin{array}{l}\mathrm{C} 18 \text { column }(250 \mathrm{~mm} \times 4.6 \mathrm{~mm}, 4 \mu \mathrm{m}) \text {, mixture of } 0.02 \mathrm{~mol} / \mathrm{L} \\
\text { potassium dihydrogen phosphate and methanol (volume ratio } \\
\text { of 90:10) with } \mathrm{pH} 2.0, \mathrm{UV} \text { detection at } 228 \mathrm{~nm}\end{array}$ & $\begin{array}{l}\text { Linear correlation of the method was } 0.9999 \text {, the } \\
\text { standard deviation was } 0.20 \text { and the average } \\
\text { recovery was } 99.78 \% \text {. }\end{array}$ & [24] \\
\hline $\begin{array}{l}\text { lon } \\
\text { chromatography }\end{array}$ & $\begin{array}{l}\text { The column was a METROSEP A SUPP } 5,6.1006 .530,(250 \mathrm{~mm} \times \\
4.0 \mathrm{~mm}) 5 \mathrm{\mu m} \text { particles of Polyvinyl alcohol with quaternary } \\
\text { ammonium groups. The mobile phase has consists of } 504 \mathrm{mg} \\
\text { of sodium bicarbonate and } 53 \mathrm{mg} \text { of sodium carbonate in } 1000 \\
\mathrm{~mL} \text { of water, conductivity detector }\end{array}$ & $\begin{array}{l}\text { LOD and LOQ } 33 \mu \mathrm{g} / \mathrm{g} \text { and } 101 \mu \mathrm{g} / \mathrm{g} \text { respectively, } \\
\text { average recovery } 98.6 \% \text { to } 100.1 \% \text { and linearity } \\
0.999\end{array}$ & $\begin{array}{l}\text { Present } \\
\text { work }\end{array}$ \\
\hline
\end{tabular}

determination of CAA in TFM. The results of various validation parameters demonstrated that the method is specific, stability indicating sensitivity, linear, precise, and accurate. The proposed method is sensitive, simple, and user-friendly for the determination of CAA content in TFM.

\section{Abbreviations}

LOD: Limit of detection; LOQ: Limit of quantitation; IC: Ion chromatography; $\mathrm{ICH}$ : International Council for Harmonization; FDA: Food and Drug Administration; $R^{2}$ : Coefficient of determination; TFM: Teriflunomide; CAA: Cyanoacetic acid; RT: Retention time

\section{Acknowledgements}

The authors gratefully acknowledge the management of APL Research Centre (A Division of Aurobindo Pharma Ltd., Hyderabad), for giving us the opportunity to carry out the present work. The authors are also thankful to the colleagues of the Department of Chemistry, Andhra University.

\section{Authors' contributions}

MK has analyzed samples on IC instrument and completed the experimental work of the drug substance of Interest. He had completed his work under the supervision of KS and TS who helped him to detail the methodology as well as theoretical advance. CS helped him in preparing the manuscript and all authors (MK, TS, CS, and KS) read the manuscript and approved it.

\section{Funding}

Not applicable.

Availability of data and materials

All data and materials are available upon request.

\section{Declarations}

Ethics approval and consent to participate

Not applicable.

\section{Consent for publication}

Not applicable.

\section{Competing interests}

The authors declare that they have no competing interests.
Received: 23 March 2021 Accepted: 5 July 2021

Published online: 28 August 2021

\section{References}

1. Miller AE (2017) Teriflunomide in multiple sclerosis: an update. Neurodegener Dis Manag 7(1):9-29. https://doi.org/10.2217/nmt-2016-0029

2. Magne D, Mézin F, Palmer G, Guerne PA (2006) The active metabolite of leflunomide, A77 1726, increases proliferation of human synovial fibroblasts in presence of IL-1beta and TNF-alpha. Inflammation Research. 55(11):469475. https://doi.org/10.1007/s00011-006-5196-x

3. Marriott JJ, O'Connor PW (2010) Emerging therapies in relapsing-remitting multiple sclerosis. Rev Recent Clin Trials 5(3):179-188. https://doi.org/10.21 74/157488710792007275

4. Bruneau JM, Spinella Jaegle S, Fudali C, Woodward K, Robson PA, Sautes C (1998) Purification of human dihydro-orotate dehydrogenase and its inhibition by A77 1726, the active metabolite of leflunomide. Biochem J 336(2):299-303. https://doi.org/10.1042/bj3360299

5. O'connor PW, Li D, Freedman MS, Bar-Or A, Rice GP, Confavreux C (2006) A Phase II study of the safety and efficacy of teriflunomide in multiple sclerosis with relapses. Neurology 66(6):894-900. https://doi.org/10.1212/01. wnl.0000203121.04509.31

6. Helliwell $\mathrm{CL}$, Coles AJ (2009) Monoclonal antibodies in multiple sclerosis treatment: current and future steps. Ther Adv Neurol Disord 2(4):195-203. https://doi.org/10.1177/1756285609337827

7. Vollmer T (2009) MS Therapies in the Pipeline: Teriflunomide. EMS News

8. Sanofi. Aubagio (teriflunomide oral tablets)( 2012) US prescribing information. http://products.sanofi.us/aubagio/aubagio.pdf.

9. Sanofi-Aventis. Aubagio (teriflunomide film-coated tablets) (2013) EU summary of product characteristics. http://www.ema.europa.Eu/docs/en_ GB/documentlibrary/EPAR_-_Product_Information/human/002514/WC50014 8682.pdf

10. International Conference on Harmonization of technical requirements for registration of Pharmaceuticals for human use, Q3A (R2), Impurities in new drug substances, 2006.

11. Vishwas TS, Gurupadayya BM, Jain R (2019) "NOVEL HPTLC-DENSITOMETRIC METHOD FOR THE ESTIMATION OF TERIFLUNOMIDE IN TABLET DOSAGE FORM". Int J Pharm Pharm Sci. https://doi.org/10.22159/ijpps.2019v11i6.31 742

12. Sobhani K, Garrett DA, Liu DP, Rainey PM (2010) A rapid and simple highperformance liquid chromatography assay for the leflunomide metabolite, teriflunomide (A77 1726), in renal transplant recipients. Am J Clin Pathol 133(3):454-457. https://doi.org/10.1309/AJCPR23YAOYFSZTX

13. Schmidt A, Schwind B, Gillich M, Brune K, Hinz B (2003) Simultaneous determination of leflunomide and its active metabolite, A77 1726, in human plasma by high-performance liquid chromatography. Biomed Chromatogr 17(4):276-281. https://doi.org/10.1002/bmc.244 
14. Nadella NP, Ratnakaram VN, Srinivasu N (2017) Quality-by-design-based development and validation of a stability-indicating UPLC method for quantification of teriflunomide in the presence of degradation products and its application to in vitro dissolution. J Liq Chromatogr Relat Technol 40(10): 517-527. https://doi.org/10.1080/10826076.2017.1330211

15. Mehta B, Prajapat $P$, Gohil $Y$ (2017) Development and validation of stability indicating RP-HPLC method for estimation of teriflunomide in an active pharmaceutical ingredient. J Pharm Innov 6:440-449

16. Yao X, Liu Y, Song L, Jiang J, Xiao F, Liu D, Hu P (2018) Development of a simple HPLC-MS/MS method to simultaneously determine teriflunomide and its metabolite in human plasma and urine: Application to clinical pharmacokinetic study of teriflunomide sodium and leflunomide. Biomedical Chromatography 33:e4420. https://doi.org/10.1002/bmc.4420

17. Rule, G. S., Rockwood, A. L., \& Johnson-Davis, K. L. (2019). LC-MS/MS Method for the Quantification of the Leflunomide Metabolite, Teriflunomide, in Human Serum/Plasma. Methods in molecular biology (Clifton, N.J.), 1872, 75-83. https://doi.org/10.1007/978-1-4939-8823-5_8

18. Parekh JM, Vaghela RN, Sutariya DK, Sanyal M, Yadav M, Shrivastav PS (2010) Chromatographic separation and sensitive determination of teriflunomide, an active metabolite of leflunomide in human plasma by liquid chromatography-tandem mass spectrometry. J Chromatogr B Analyt Technol Biomed Life Sci. 878(24):2217-2225. https://doi.org/10.1016/j. jchromb.2010.06.028

19. Suneetha A, Rajeswari R (2015) Estimation of Teriflunomide Along with Concomitant Drugs in Different Biological Matrices Using LC-MS/MS. Int J Pharm Sci Res 6(5):1915-1923. https://doi.org/10.13040/IJPSR.0975-8232.6(5)0

20. Lovelady HG (1962) Modified Method for Spectrophotometric Determination of Cyanoacetic Acid in Blood Plasma. Analytical Chemistry 34(10):1344-1344. https://doi.org/10.1021/ac60190a052

21. Marek EM (2004) Gas Chromatographic Determination of Cyanoacetic Acid and Sodium Cyanoacetate. Pharmaceutical Chemistry Journal 35(8):461-464. https://doi.org/10.1023/a:1013700826567

22. Sievert HW, Lipton SH, Strong FM (1960) Quantitative determination of cyanoacetic acid as an enzymic product of $\beta$-aminopropionitrile. Archives of Biochemistry and Biophysics 86(2):311-316. https://doi.org/10.1016/00039861(60)90424-0

23. Schwarz M, Bodenstein OF, Fales JH (1971) Compounds Related to Cyanoacetic Acid as Repellents for Cockroaches. I11,3. Journal of Economic Entomology 64(3):576-578. https://doi.org/10.1093/jee/64.3.576

24. Xiao-yi XIONG, An-qun CHEN, Yong-mei HE (2010) (Chongqing Unis Chemical Co.,Ltd.,Chongqing 402161,China);Analysis of Cyanoacetic Acid Content by HPLC[J]. Chemical Industry, Guangzhou, pp 2-12

25. Bhattacharyya L (2012) Ion Chromatography-Principles and Applications. Applications of Ion Chromatography for Pharmaceutical and Biological Products:1-21. https://doi.org/10.1002/9781118147009.ch1

26. Novič M, Haddad PR (2012) Retention Processes in lon-Exclusion Chromatography: A New Perspective. Applications of lon Chromatography for Pharmaceutical and Biological Products:23-47. https://doi.org/10.1002/ 9781118147009.ch2

27. Jenke D (2011) Application of Ion Chromatography in Pharmaceutical and Drug Analysis. Journal of Chromatographic Science; https://doi.org/10.1093/ chrsci/49.7.524 49(7):524-539

28. Kumar MN, Reddy VK, Sharma HK, Kaleemullah T, Reddy PM, Prasanna SJ, Reddy GT, Rao MN (2011) Simple and sensitive ion chromatography method for the simultaneous determination of Dimethyl sulfate and Diethyl sulfate contents in Metoprolol tartrate drug substance. Der Chemica Sinica 2(6):164-172

29. Santana MH, Maldaner AO, Fraga WG, Almeida FV (2017). Direct Determination of N-Nitrosoglyphosate in Technical Glyphosate Using lon Chromatography with UV Detection J. Braz. Chem. Soc; https://doi.org/10.21 577/0103-5053.20160280.

30. Chen ML, Ye ML (2014) Determination of Zoledronic Acid and Four Common Anions in Zoledronic Acid Injection by Gradient Ion Chromatography with a Self-Regeneration Suppressor. Open Access Library Journal 1:e827 https://doi.org/10.4236/oalib.1100827
31. International Conference on Harmonization of technical requirements for registration of Pharmaceuticals for human use, Q2 (R1), Validation of Analytical Procedures: Text and Methodology, 2005.

32. FDA, Food and Drug Administration, Guidance for industry: Analytical Procedures and MethodsValidation (1994).

33. FDA, Food and Drug Administration, Center of Drug Evolution and Research, Reviewer Guidance, Validation of Chromatographic Methods 1994.

\section{Publisher's Note}

Springer Nature remains neutral with regard to jurisdictional claims in published maps and institutional affiliations.

\section{Submit your manuscript to a SpringerOpen ${ }^{\circ}$ journal and benefit from:}

- Convenient online submission

- Rigorous peer review

- Open access: articles freely available online

- High visibility within the field

- Retaining the copyright to your article

Submit your next manuscript at $\boldsymbol{\nabla}$ springeropen.com 